\title{
EFFECTS OF ETIFOXINE ON LEARNING AND MEMORY OF INTACT RATS
}

\author{
V. Kokova*, E. Apostolova, L. Peychev \\ Department of Pharmacology and Drug Toxicology, Faculty of Pharmacy, Medical University, \\ Plovdiv, Bulgaria
}

\begin{abstract}
Etifoxine (ETX) is a non-benzodiazepine anxiolytic. There is no data available showing the effect of ETX on the cognitive functions of laboratory animals. PURPOSE. The aim of this study is to investigate the effects of ETX on the cognitive functions of intact rats. METHODS. Male Wistar rats (3 groups of 10) were treated intraperitoneally with: saline, ETX in doses of 50 and $100 \mathrm{mg} / \mathrm{kg} \mathrm{b.w.,} \mathrm{respectively.} \mathrm{The}$ influence on cognition was examined using automatic reflex conditioner (shuttle box). The following parameters were assessed: number of conditioned responses (avoidances), number of unconditioned responses (escapes), latency time and number of intertrial crossings. RESULTS. The animals receiving ETX in a dose of $50 \mathrm{mg} / \mathrm{kg}$ were found to improve their learning abilities and preserve their long-term memory compared to the controls. The animals treated with the higher dose ETX were found to decrease the number of avoidances, escapes and intertrial crossings compared to the control group. CONCLUSIONS. ETX at the lower dose has a better effect on learning and memory compared to the control. ETX at the higher dose of $100 \mathrm{mg} / \mathrm{kg}$ has a worse effect compared to the control. But no significant differences between the experimental groups and the control group were found.
\end{abstract}

Key words: etifoxine, anxiolytic, cognitive function, shuttle-box test, animals

\section{INTRODUCTION}

Anxiety is a recognized symptom of many psychiatric disorders, including generalized anxiety disorder (GAD), social anxiety disorder (SAD), obsessive-compulsive disorder (OCD), and posttraumatic stress disorder (PTSD) (1). The clinicians have several treatment approaches, but "the optimum anxiolytic compound" has not been developed yet. One approach is the use of antidepressants. Selective serotonin reuptake inhibitors (SSRI) and serotonin-norepinephrine reuptake inhibitors (SNRI) are generally considered as the first-line treatment option (2). These compounds lack tolerance development and abuse potential but take several weeks to work and also cause unwanted side effects. Another approach is the use of a benzodiazepine. By contrast, benzodiazepines (BZDs) have a quick onset of action but they are sedative drugs causing motor coordination deficits, memory impairment and their continuous use rather quickly induces tolerance effects, dependence, abuse and withdrawal symptoms, including the potential for rebound anxiety.

\footnotetext{
*Correspondence to: Vesela Kokova, "V. Aprilov" str. 15 A, Plovdiv 4002, Bulgaria; tel. 032/602099; e-mail:vesela_uk@abv.bg
}

Etifoxine (ETX, Stresam ${ }^{(B)}$ is a nonbenzodiazepine anxiolytic. The mechanism of ETX for anxiolysis is potentiation of $\mathrm{GABA}_{\mathrm{A}}$ receptor function by a dual mode of action. It binds to $\beta 2$ and $\beta 3$ subunits of the $\mathrm{GABA}_{\mathrm{A}}$ receptor complex, an allosteric site different from that of the classical BZDs (3). Flumazenil, the benzodiazepine specific antagonist, did not interfere with its anxiolytic effect (4). In addition, EXF binds to the 18 $\mathrm{kDa}$ translocator protein (TSPO) that control synthesis of neurosteroids like allopregnanolone, an allosteric positive modulator of $\mathrm{GABA}_{\mathrm{A}}$ receptors (5-6). The intraperitoneal administration of ETX increased plasma and brain concentrations of pregnenolone, progesterone, $5 \alpha$ dihydroprogesterone and allopregnanolone by two- to four-fold independently from the adrenal glands (5). Neurosteroid biosynthesis inhibitors like finasteride, indomethacin and trilostane significantly blocked the effect of ETX (7). These data suggest that an enhancement of neurosteroidogenesis contributes to the anxiolytic effects of ETX.ETX has been show to possess anxiolytic-like properties in rodents (8-9) and in humans without sedative, myorelaxant and 
KOKOVA V., et al.

amnesic side effects at anxiolytic doses (1012). The most common adverse effect is drowsiness at the beginning of therapy. It does not usually cause any withdrawal syndromes (13). There is no data available showing the effect of ETX on the cognitive functions of laboratory animals.

\section{PURPOSE}

The aim of the current study is to define the effects of ETX on learning and memory of intact rats.

\section{MATERIALS AND METHODS}

All experiments were carried out according to the guidelines for the use of laboratory animals in EU and Bulgaria. Official permission for the study was obtained by Bulgarian Food Safety Agency No 87/9.01.2014.

\section{Drug}

Etifoxine - 2-ethylamino-6-chloro-4-methyl-4phenyl-4H-3,1benzoxazine hydrochloride (Stresam ${ }^{\circledR}$, Biocodex, Gentilly, France).

\section{Animals}

In this study, 30 male Wistar rats with 170-220 $\mathrm{g}$ body weight were used, divided in 3 groups $(n=10)$. The rats were kept under standard laboratory conditions in an 08:00-20:00 h light/dark cycle and provided with food and water at libitum. The animals were treated once daily intraperitoneally respectively with: $1^{\text {st }}$ group (control)- saline $(0.1 \mathrm{ml} / 100 \mathrm{~g}) ; 2^{\text {nd }}$ ETX $50 \mathrm{mg} / \mathrm{kg}$ and $3^{\text {rd }}$ group- ETX $100 \mathrm{mg} / \mathrm{kg}$.

\section{Behavioral tests}

An automatic reflex conditioner for active avoidance "shuttle box" (Ugo Basile, Italy) was used in studying learning in rats. Training lasted 5 consecutive days with 30 training sessions daily, each consisting of a 6-second light and sound stimulus $(670 \mathrm{~Hz}$ and $70 \mathrm{~dB})$, and electrostimulation $(0.4 \mathrm{~mA})$ in the last 3 seconds delivered through the cage grid floor. Each session was followed by 12 seconds of rest. Seven days after this training session (day 12) retesting was done for one day with the same parameters to track the storage of memory traces. The following parameters were assessed: number of conditioned responses (avoidances), number of unconditioned responses (escapes), latency time and number of intertrial crossings.

\section{Statistical analysis}

All data are expressed as mean \pm standard error of the mean (SEM). Statistical comparisons were done by One way ANOVA and Pairedsamples T test of SPSS.19, after verifying the normality of distribution by a KolmogorofSmirnov test. For data not normally distributed Two independent samples test and Two related samples test were used. Differences were considered to be statistically significant for $\mathrm{p} \leq$ 0,05 .

\section{RESULTS}

In the shuttle-box active avoidance test, the control group showed a statistically significant increase of the number of avoidances on the $4^{\text {th }}$ $(6,7 \pm 1,94 \mathrm{v} / \mathrm{s} 2,4 \pm 0,69, \mathrm{p} \leq 0,01), 5^{\text {th }}(9,9 \pm 2,5$ $\mathrm{v} / \mathrm{s} 2,4 \pm 0,69, \mathrm{p} \leq 0,01)$ and $12^{\text {th }}$ days $(9,3 \pm 2,35$ $\mathrm{v} / \mathrm{s} 2,4 \pm 0,69, \mathrm{p} \leq 0,01)$ compared to the number on the $1^{\text {st }}$ day of experiment. The rats treated with ETX in a dose of $50 \mathrm{mg} / \mathrm{kg}$ showed a tendency of increase in the number of conditioned responses in comparison with the control on the $2^{\text {nd }}, 3^{\text {rd }}, 5^{\text {th }}$ days of the learning session and in the retention session on $12^{\text {th }}$ day. We found a reduction of the number of avoidances in the group treated with the higher dose ETX $(100 \mathrm{mg} / \mathrm{kg})$ compared to the control group during entire training period and in the study of long-term memory, but no statistically significant difference was found (Figure 1).

In the active avoidance test, the control group showed a significant decrease in the number of escapes on the $2^{\text {nd }}(\mathrm{p} \leq 0,001), 3^{\text {rd }}, 4^{\text {th }}, 5^{\text {th }}$ and $12^{\text {th }}$ days $(\mathrm{p} \leq 0,05)$ compared to the $1^{\text {st }}$ day (Figure 2). The animals treated with ETX in a dose of $50 \mathrm{mg} / \mathrm{kg}$ had increased the number of escapes on days 4 and 5 of training session and in the memory retention test on day 12 compared with the controls. There was a significant reduction of unconditioned responses in animals treated with ETX in a dose of $100 \mathrm{mg} / \mathrm{kg}$ on days 1 and 3 of training session compared to the controls $(\mathrm{p} \leq 0,05)$.

Analyzing the latency time, the group treated with ETX in a dose of $100 \mathrm{mg} / \mathrm{kg}$ showed a tendency to increase this parameter compared to the control (Figure 3).

The animals treated with ETX in a dose of 50 $\mathrm{mg} / \mathrm{kg}$ had increased the number of intertrial crossings with no significant difference on days $1,2,3,4,5$ and 12 compared to the controls. The experimental group treated with ETX in a dose of $100 \mathrm{mg} / \mathrm{kg}$ had decreased the number of intertrial crossings on days 1, 2, 3, 4 and 12 compared to the controls, but no significant difference was found (Figure 4). 


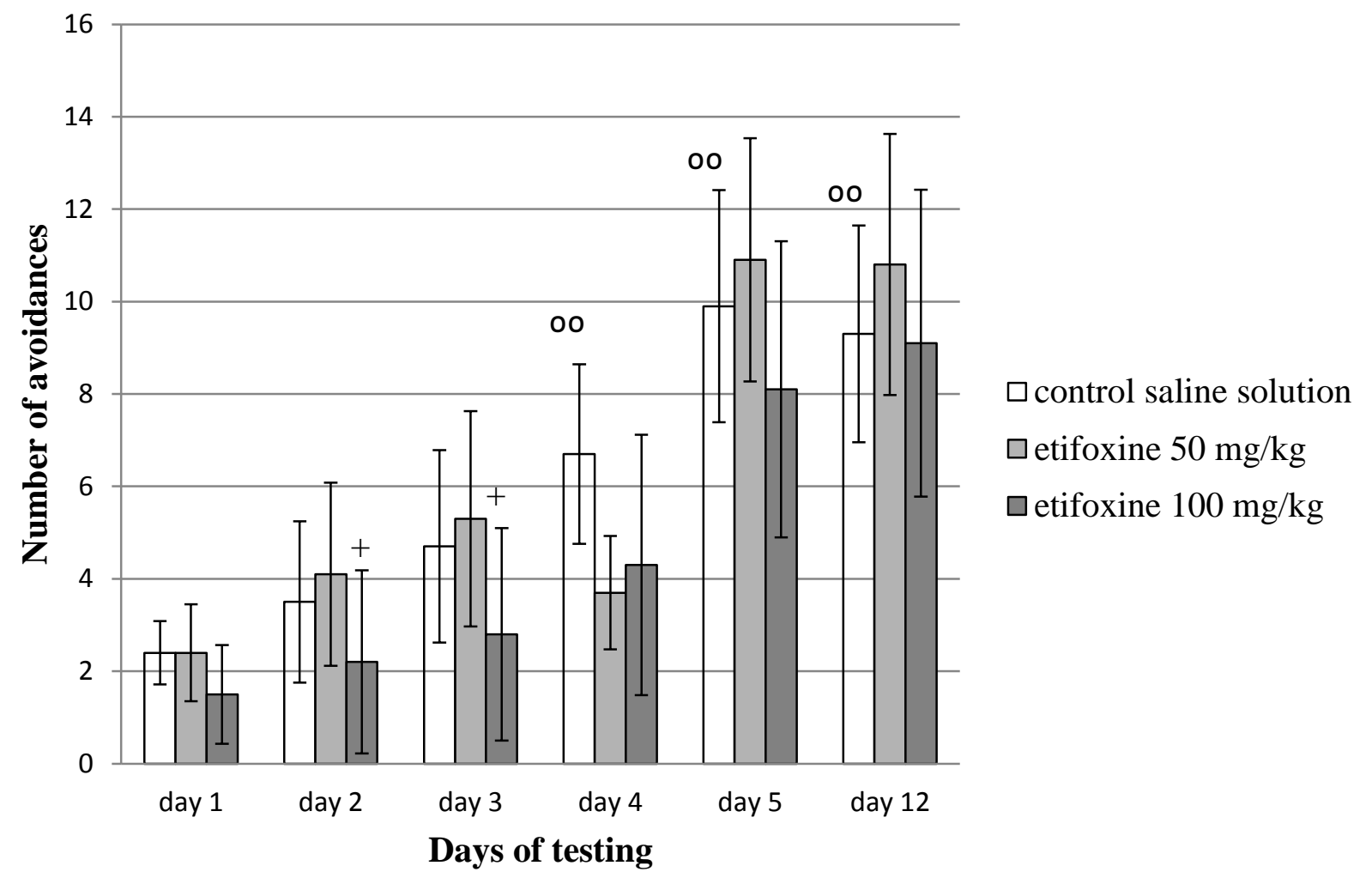

Figure 1. Effects of ETX on the number of conditioned responses (avoidances) in active avoidance test (shuttle box) in rats. ${ }^{o 0} \mathrm{p} \leq 0,01$ compared to the $1^{\text {st }}$ day control saline solution; $+\mathrm{p} \leq 0,05$ compared to the same day of animals treated with EFX $50 \mathrm{mg} / \mathrm{kg}$.

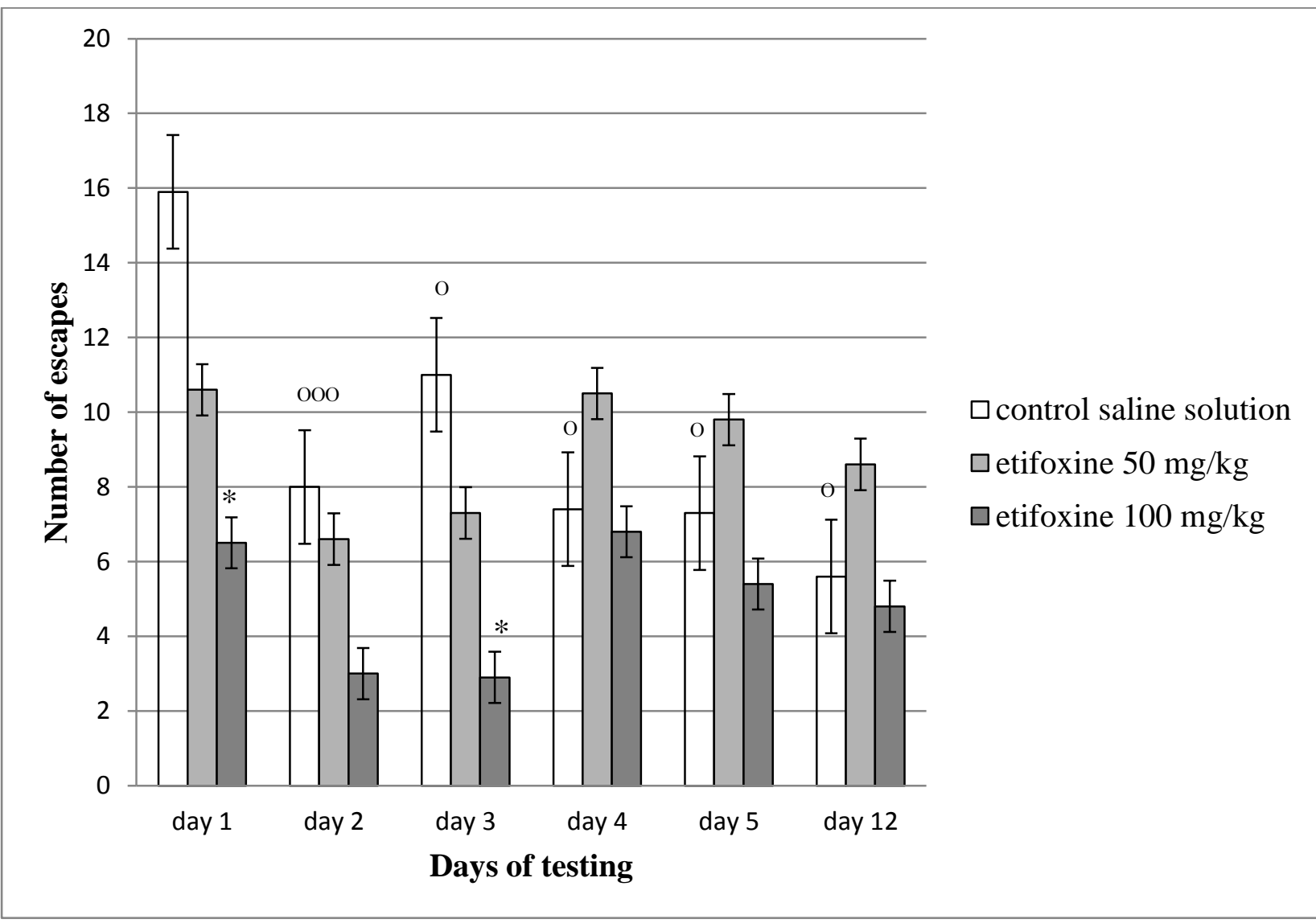

Figure 2. Effects of ETX on the number of unconditioned responses (escapes) in active avoidance test (shuttle box) in rats. ${ }^{\circ} \mathrm{p} \leq 0,05$ and ${ }^{\text {ooo }} \mathrm{p} \leq 0,001$ compared to the $1^{\text {st }}$ day control saline solution; ${ }^{*} \mathrm{p} \leq$ 0,05 compared to the control saline solution for the respective day. 


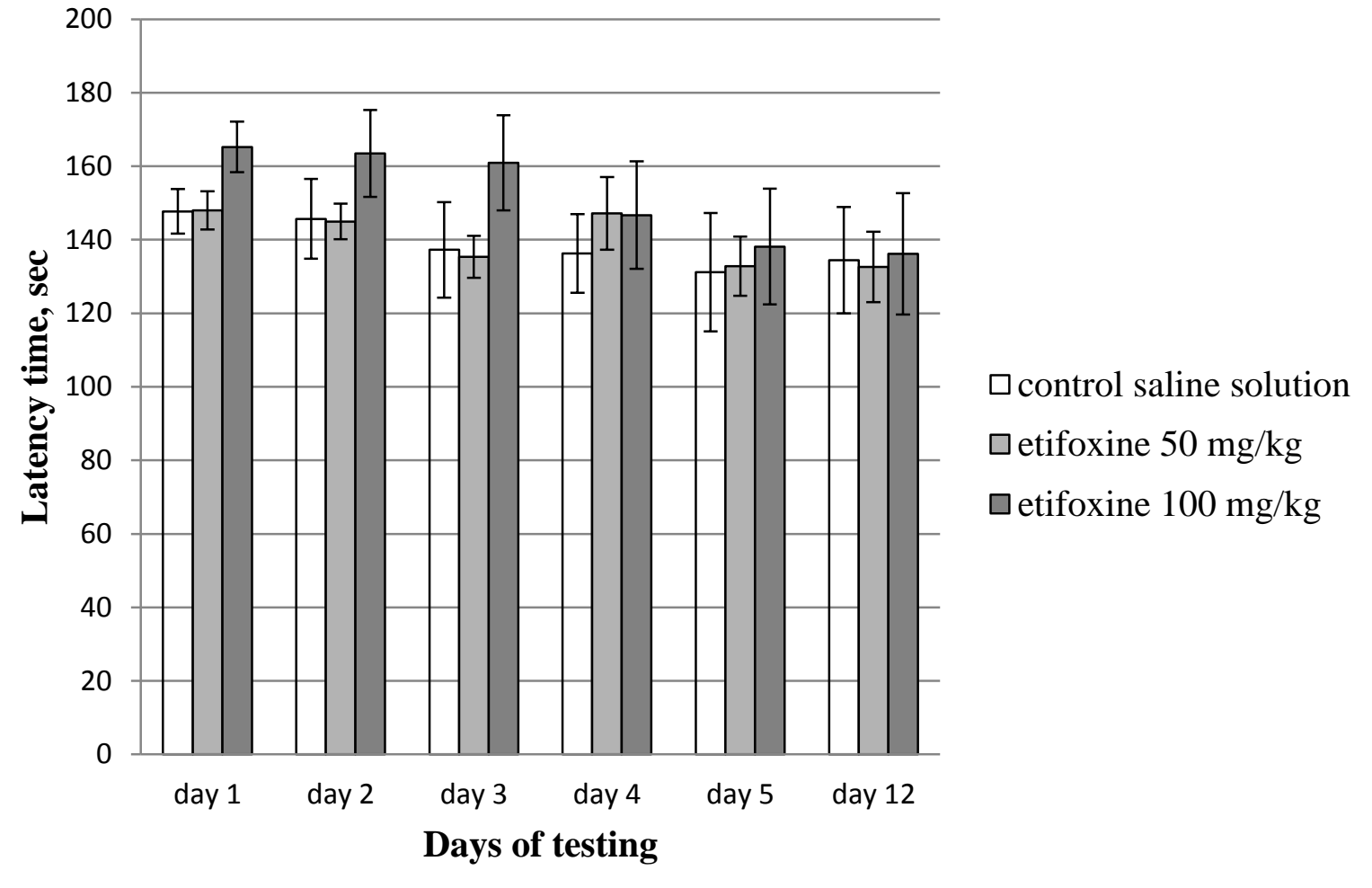

Figure 3. Effects of ETX in active avoidance test (shuttle box): latency time.

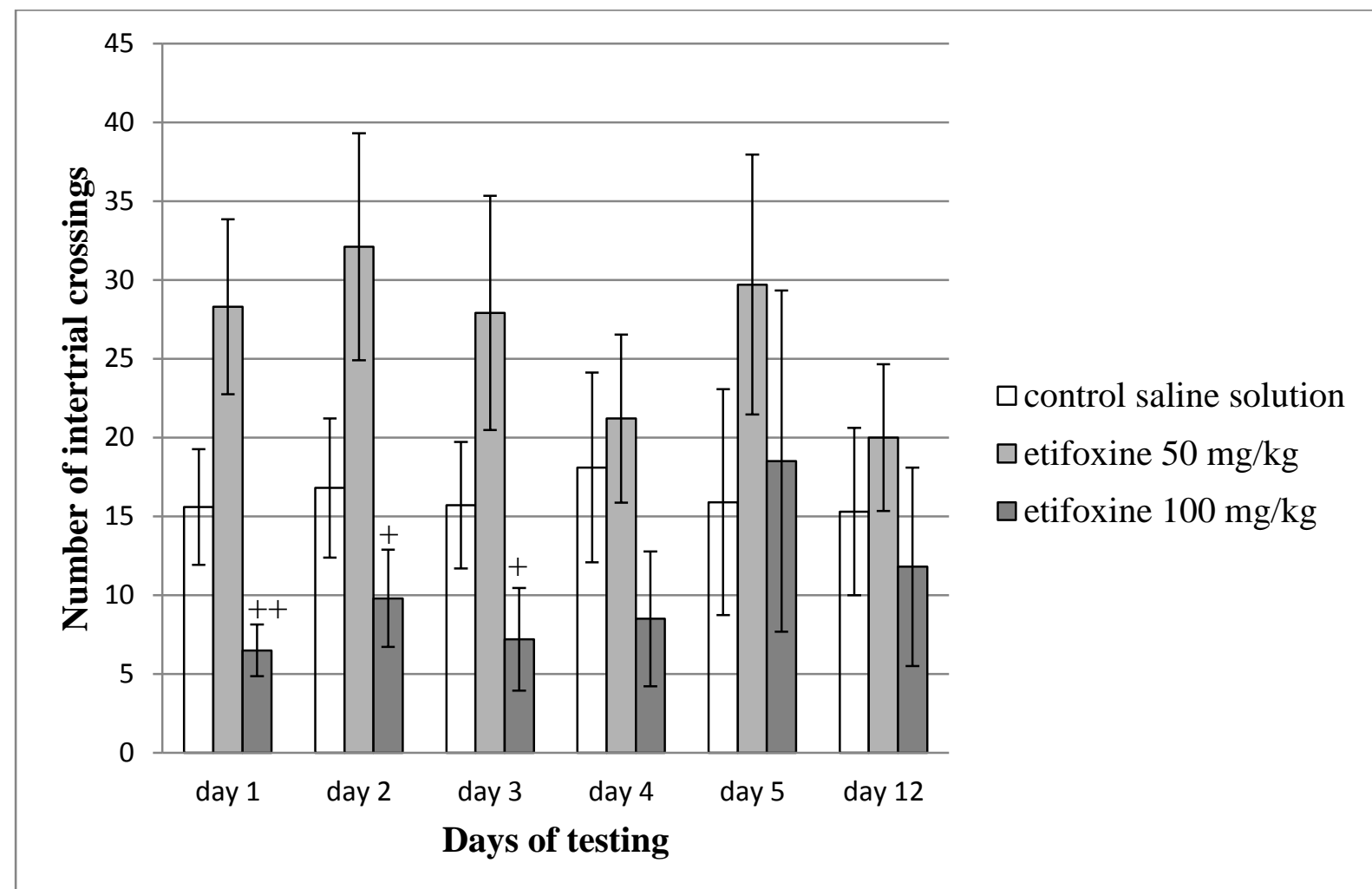

Figure 4. Effects of ETX in active avoidance test (shuttle box): number of intertrial crossings. $+p \leq 0,05$ and ++ $\mathrm{p} \leq 0,01$ compared to the same day of animals treated with EFX $50 \mathrm{mg} / \mathrm{kg}$.

\section{DISCUSSION}

In vivo, the i.p. administration of ETX (50 $\mathrm{mg} / \mathrm{kg}$ ) was associated with increased concentrations of pregnenolone, progesterone, $5 \alpha$ - dihydroprogesterone and allopregnanolone in plasma and brain of sham-operated animals (5). Pregnenolone increase and allopregnanolone impairs memory performances (14). There is no data available in the scientific literature showing the effect of ETX on the cognitive functions of laboratory animals. Clinical studies describe that ETX preserves attention, memory and psychomotor functions (11-12). The results of a double blind 
parallel group placebo controlled comparison of sedative and amnesic effects of ETX and lorazepam suggest that 50 and $100 \mathrm{mg}$ single dose of ETX do not induce amnesia and sedation as compared to lorazepam in humans (10). Data are consistent with our results obtained about the cognitive functions in rats. The animals receiving ETX in a dose of 50 $\mathrm{mg} / \mathrm{kg}$ were found to improve their learning abilities and preserve their long-term memory compared to the controls with no significant difference. The animals treated with the higher dose ETX were found to decrease the number of avoidances, escapes and intertrial crossings compared to the control group, but no significant difference was observed. ETX has the tendency to increase the number of measured parameters in a dose of $50 \mathrm{mg} / \mathrm{kg}$ and to decrease them in a dose of $100 \mathrm{mg} / \mathrm{kg}$ in comparison to the controls. But no significant differences between the experimental groups and the control group were found.

\section{CONCLUSIONS}

ETX at the lower dose of $50 \mathrm{mg} / \mathrm{kg}$ has a better effect in the active avoidance test compared to the control and this can be an advantage to other anxiolytics. ETX at the higher dose of $100 \mathrm{mg} / \mathrm{kg}$ has a worse effect on learning and memory in the active avoidance test compared to the control.

\section{REFERENCES}

1. Farb, DH. and Ratner, MH., Targeting the modulation of neural circuitry for the treatment of anxiety disorders. Pharmacol Rev, 66:1002-32, 2014.

2. Bandelow, B., Zohar, J., Hollander, E., Kasper, S., Moller, HJ. et al., World Federation of Societies of Biological Psychiatry (WFSBP) guidelines for the pharmacological treatment of anxiety, obsessive-compulsive and post-traumatic stress disorders - first revision. World $J$ Biol Psychiatry, 9:248-312, 2008.

3. Hamon, A., Morel, A., Hue, B., Verleye, M. and Gillardin, J.M., The modulatory effects of the anxiolytic etifoxine on GABA (A) receptors are mediated by the beta subunit. Neuropharmacology, 45:293-303, 2003.

4. Verleye, M., Schlichter, R. and Gillardin, J.M., Interactions of etifoxine with the chloride channel coupled to the GABA (A) receptor complex. Neuroreport, 10:320710, 1999.

5. Verleye, M., Akwa, Y., Liere, P., Ladurelle, N., Pianos, A., Eychenne, B., Schumacher, M. and Gillardin, J.M., The anxiolytic etifoxine activates the peripheral benzodiazepine receptor and increases the neurosteroid levels in rat brain. Pharmacol. Biochem. Behav., 82:712-720, 2005.

6. Papadopoulos, V., Baraldi, M., Guilarte, TR., Knudsen, TB., Lacapère, JJ., Lindemann, P. et al., Translocator protein (18kDa): new nomenclature for the peripheral-type benzodiazepine receptor based on its structure and molecular function. Trends PharmacolSci, 27:402-9, 2006.

7. Ugale, R., Sharma, A., Kokare, D. et al., Neurosteroid allopregnanolone mediates anxiolytic effect of etifoxine in rats. Brain research, 1184:193-201, 2007.

8. Boissier, JR., Simon, P., Zaczinska, M. and Fichelle, J., Experimental psychopharmacologic study of a new psychotropic drug, 2-ethylamino-6chloro-4methyl-4phenyl-4H-3,1benzoxazine.

Therapie, 27:325-38, 1972.

9. Schlichter, R., Rybalchenko, V., Poisbeau, P., Verleye, M. and Gillardin, J., Modulation of GABAergic synaptic transmission by the non-benzodiazepine anxiolytic etifoxine. Neuropharmacology, 39:1523-35, 2000.

10.Micallef, J., Soubrouillard, C., Guet, F., Le Guern, ME., Alquier, C., Bruguerolle, B. et al., A double blind parallel group placebo controlled comparison of sedative and amnesic effects of etifoxine and lorazepam in healthy subjects [corrected]. Fundam Clin Pharmacol, 15:209-16, 2001.

11.Nguyen, N., Fakra, E., Pradel, V., Jouve, E., Alquier, C., LeGuern, ME. et al., Efficacy of etifoxine compared to lorazepam monotherapy in the treatment of patients with adjustment disorders with anxiety: a double-blind controlled study in general practice. Hum Psychopharmacol, 21:139-49, 2006.

12.Servant, D., Graziani, PL., Moyse, D. and Parquet, PJ., Treatment of adjustment disorder with anxiety: efficacy and tolerance of etifoxine in a double-blind controlled study. Encephale, 24:569-74, 1998.

13.Yun, MCh. and Kyung, HK., Etifoxine for Pain Patients with Anxiety. The Korean Journal of pain, 28:4-10, 2015.

14.Ladurelle, N., Eychenne, B., Denton, D., Blair-West, J., Schumacher, M., Robel, P. et al., Prolonged intracerebroventricular infusion of neurosteroids affects cognitive performances in the mouse. Brain Res, 858:371-9, 2000. 